\title{
A new find of Arabidopsis neglecta (Brassicaceae) in the Svydovets Massif (Ukrainian Carpathians)
}

\author{
Clemens PACHSCHWÖLL, Tetiana PACHSCHWÖLL \\ Department of Botany and Biodiversity Research, University of Vienna \\ 14 Rennweg, Vienna 1030, Austria \\ clemens.pachschwoell@univie.ac.at \\ tetiana.pachschwoell@univie.ac.at
}

\begin{abstract}
Pachschwöll C., Pachschwöll T. 2019. A new find of Arabidopsis neglecta (Brassicaceae) in the Svydovets Massif (Ukrainian Carpathians). Ukrainian Botanical Journal, 76(1): 60-66.

Abstract. A new population of the Pancarpathian endemic species Arabidopsis neglecta was discovered in the Svydovets Massif at Komyn in 2018. It is the fifth population known so far for the Svydovets. A short description of the subalpine-alpine scree habitat (Rumici scutati-Rhodioletum roseae) is given. Many of the co-occuring species are listed in the Red Data Book of Ukraine (2009); however, A. neglecta is not included in the current edition of the Red Data Book of Ukraine. Though, its micropopulations on steep slopes of glacial cirques are highly vulnerable due to climate change and some other factors. Keywords: Cardaminopsis neglecta, Carpathian Biosphere Reserve, floristic record, rare species, Ukraine
\end{abstract}

Пахшвьоль К., Пахшвьоль Т. Нова знахідка Arabidopsis neglecta (Brassicaceae) на території масиву Свидовець (Українські Карпати). Український ботанічний журнал, 2019, 76(1): 60-66.

Реферат. Нова популяція карпатського ендеміка Arabidopsis neglecta була виявлена на г. Комин на території Свидовецького масиву Карпатського біосферного заповідника в 2018 р. Це п’ята популяція цього виду, виявлена на даний час в межах масиву Свидовець. Подано стислий опис субальпійсько-альпійського оселища (Rumici scutatiRhodioletum roseae) на щебнистому схилі. На відміну від A. neglecta, більшість видів цього угруповання включені в Червону книгу України (2009). Відмічено, що мікропопуляції даного виду на крутих схилах гляціальної арени перебувають під значною загрозою через зміни клімату.

Ключові слова: Карпатський біосферний заповідник, рідкісний вид, флористична знахідка, Україна, Cardaminopsis neglecta

\section{Introduction}

Arabidopsis neglecta (Schult.) O'Kane \& Al-Shehbaz (= Cardaminopsis neglecta (Schult.) Hayek, Arabis neglecta Schult.) is a Pancarpathian endemic species occurring in Poland, Slovakia, Romania and Ukraine (Marhold, 2011; Hurdu etal., 2012; Kliment etal., 2016). It grows in subalpine to alpine screes of intermediate to siliceous bedrock like sandstone flysch and crystalline schists (Sychowa, 1985; Chopyk, Fedoronchuk, 2015; Bartók et al., 2016). For the Ukrainian Carpathians, it has been considered as "Vulnerable" (VU) and "Data Deficient" (DD) by Malinovski et al. (2002), or even as "Endangered" (EN) by Kricsfalusy and Budnikov (2007), but has not been included later in the $3^{\text {rd }}$ edition of the Red Data Book of Ukraine (Chervona knyha..., 2009). As pointed out by Kobiv (2011, 2017, 2018), this perennial, short-lived glareophyte is definitely a (C) C. PACHSCHWÖLL, T. PACHSCHWÖLL, 2019 rare and threatened mountain species of the Ukrainian Carpathians where it occurs in the following mountain ranges: Chornohora, Svydovets, Marmarosh, and Chyvchyny Mts. (Kotov, 1953; Malinovski et al., 2002; Bedei, 2006; Chopyk, Fedoronchuk, 2015; Novikoff, Hurdu, 2015).

In the Svydovets Massif, only four populations have been known so far (Fig. 1). The first one can be found in a famousglacial cirque (c. $48^{\circ} 13^{\prime} 08^{\prime \prime} \mathrm{N}, 24^{\circ} 14^{\prime} 17^{\prime \prime} \mathrm{E}$ ) below Mt. Blyznytsia Velyka and Mt. Blyznytsia Mala that is part of the Carpathian Biosphere Reserve and harbours several rare high-mountain species, such as Antennaria carpatica (Wahlenb.) Bluff \& Fingerh., Hedysarum hedysaroides (L.) Schinz \& Thell, Veronica alpina L., Erigeron alpinus and Oreochloa disticha (Wulfen) Link; the latter two are considered extinct at this locality (Klášterský, 1929; Domin, 1930; Kobiv, 2017). The second population was reported from Mt. Drahobrat (c. $\left.48^{\circ} 14^{\prime} 04^{\prime \prime} \mathrm{N}, 24^{\circ} 13^{\prime} 58^{\prime \prime} \mathrm{E}\right)$ by Margittai (1935: 89); it 


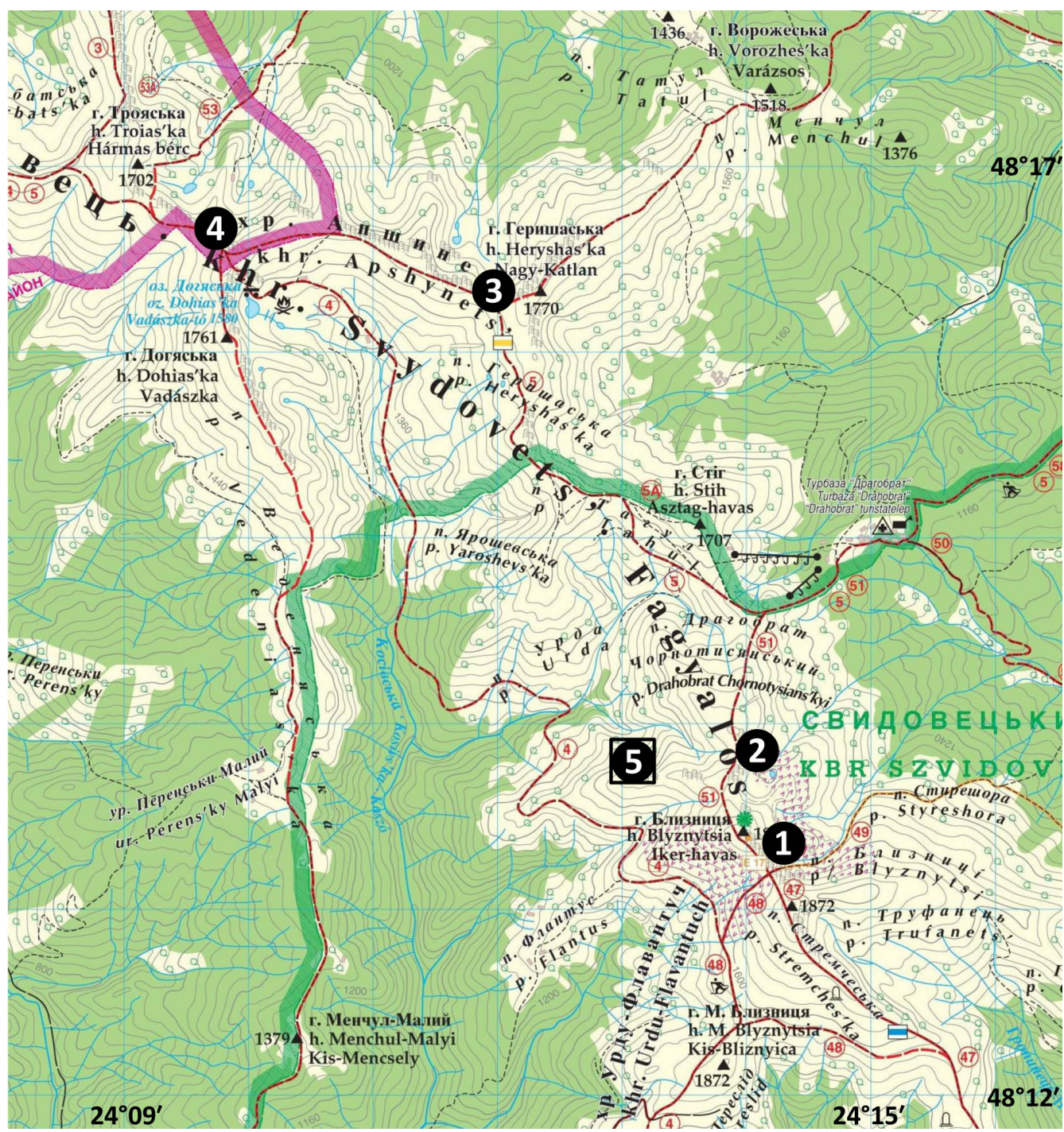

Fig. 1. Distribution of Arabidopsis neglecta in the Svydovets Massif (Ukrainian Carpathians). Populations 1-5 according to the text. The newly discovered population no. 5 at Komyn is emphasized with a black square. Green line: boundary of the Carpathian Biosphere Reserve. Purple Line: boundary of the districts Rakhiv and Tiachiv. Modified from: A Máramarosihavasok turistatérképe, 2. Kiadás, 1 : 50 000, Kárpátia Térképmühely Ktf. 2008

lies within a part of the Carpathian Biosphere Reserve but is now unconfirmed. The third one was reported also by Margittai (1935: 89) for Mt. Gereshaska [Heryshas'ka] (c. 48 $16^{\prime} 17^{\prime \prime} \mathrm{N}, 24^{\circ} 12^{\prime} 06^{\prime \prime} \mathrm{E}$ ) and could be considered confirmed by Chopyk (herbarium voucher in KW). The fourth locality at Mt. Trojaska/polonyna Apshynets $\left(48^{\circ} 16^{\prime} 38.7^{\prime \prime} \mathrm{N}, 24^{\circ} 09^{\prime} 36.5^{\prime \prime} \mathrm{E}, 1640 \mathrm{~m}\right.$ a.s.1., NE-exposed) was discovered only recently by Kobiv et al. (2009) and is very close to the previous one; see also Kobiv (2011) for population characterization.

\section{Material and methods}

During botanical fieldwork in the Svydovets Massif, a new population of Arabidopsis neglecta was discovered in a cirque at Komyn, c. $1.2 \mathrm{~km} \mathrm{NW}$ of the summit of Mt. Blyznytsia Velyka (no. 5 in Fig. 1). There, a handful of fruiting and vegetative individuals were growing in a scree microsite of a steep NW-exposed cliff. Due to the rarity of the species, we refrained from collecting herbarium specimens but documented its occurrence with photographs. The identification of $A$. neglecta was later confirmed with literature (Kotov, 1953; Jávorka, 


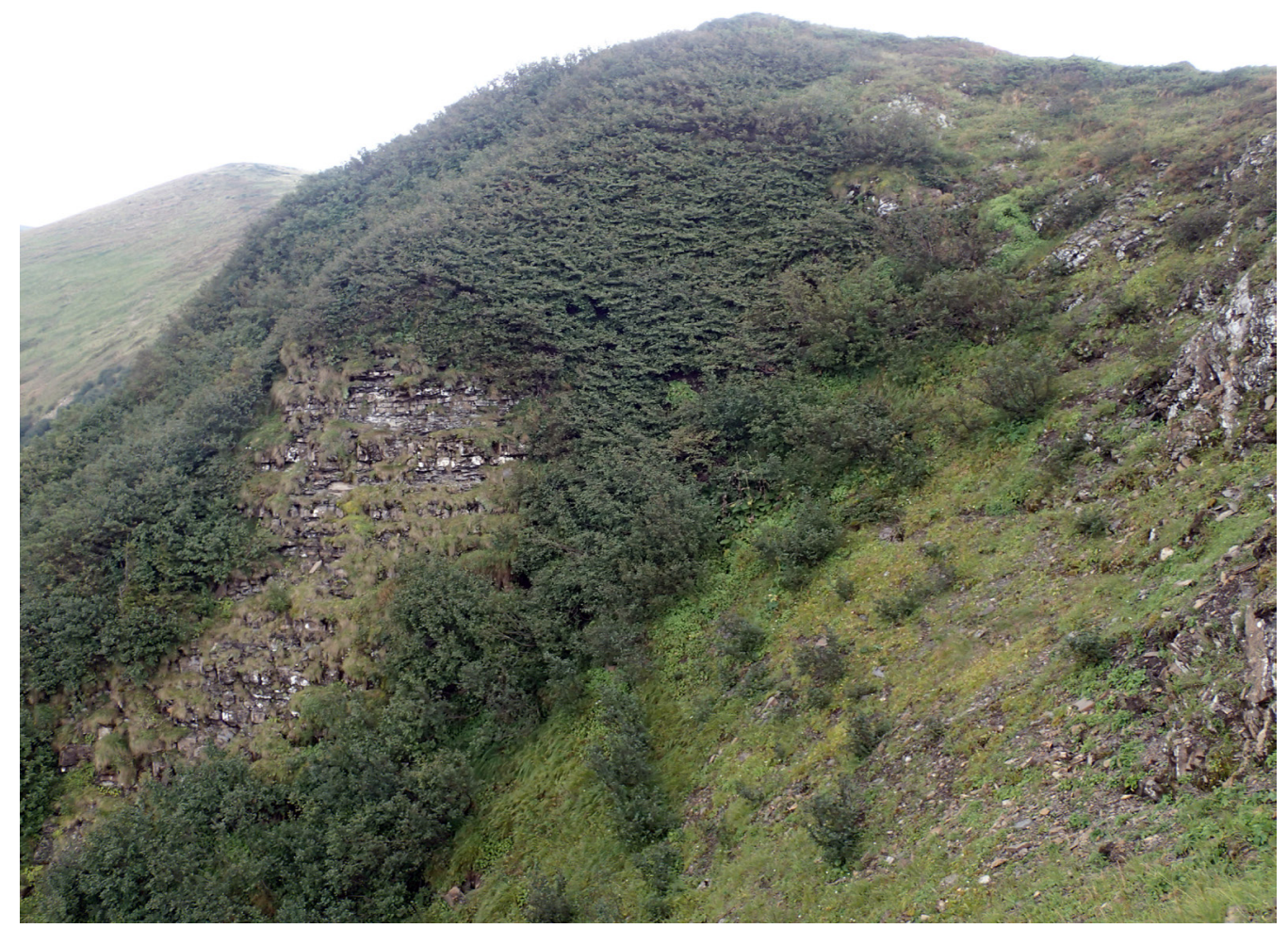

Fig. 2. Habitat of Arabidopsis neglecta at Komyn (Svydovets Massif, Ukrainian Carpathians) where this species grows at the bottom of a steep cliff surrounded by Alnus alnobetula (A. viridis). Photo by Clemens Pachschwöll, 22 August 2018

Csapody, 1979; Sychowa, 1985; Chopyk, Fedoronchuk, 2015) and by a specialist. GPS coordinates (WGS84) with an accuracy of c. $5 \mathrm{~m}$ as well as the altitude were determined with a Holux M-241 GPS logger. If not stated otherwise, nomenclature and taxonomy of taxa mentioned in this paper follow Euro+Med (2006-).

\section{Results and discussion}

Location, ecological characteristics and status of the newly discovered population of Arabidopsis neglecta in the Svydovets Massif

In the following, we present the exact location, ecological characteristics and accompanying species, see also Fig. 1-3.

Arabidopsis neglecta: Ukraine, Zakarpatska Oblast, Rakhiv Raion (District), Svydovets Massif, Carpathian Biosphere Reserve, north-exposed cirque at Komyn c. $1.2 \mathrm{~km}$ NW of Mt. Blyznytsia Velyka peak, $48^{\circ} 13^{\prime} 40.4^{\prime \prime} \mathrm{N}$, $24^{\circ} 13^{\prime} 01.4^{\prime \prime} \mathrm{E}, 1670 \mathrm{~m}$ a.s.1.

Habitat (see Fig. 2): bottom of a steep (c. $\left.70^{\circ}\right)$, NWexposed cliff of calcium-containing flysch surrounded by shrubs of Alnus alnobetula (Ehrh.) K. Koch (= A. viridis (Chaix) DC.). It harbours stairlike, densely vegetated outcrops as well as also poorly vegetated microsites.

Accompanying species: Achillea oxyloba subsp. schurii (Sch. Bip.) Heimerl, Asplenium viride Huds., Calamagrostis villosa (Chaix) J.-F. Gmel., Campanula kladniana (Schur) Witasek, Cerastium alpinum L., Doronicum columnae subsp. carpaticum (Griseb. \& Schenk) Soó (=D. carpaticum (Griseb. \& Schenk) Nyman, see Pachschwöll, 2014), Festuca amethystina subsp. orientalis Krajina ( $=F$. inarmata Schur), Galium anisophyllon Vill., Parnassia palustris L., Phyteuma orbiculare L., Primula elatior (L.) L. (incl. Primula poloninensis (Domin) Fed.), Rhodiola rosea L., Rumex scutatus L., Saussurea alpina (L.) DC., Sabulina verna (L.) Rchb. (= Minuartia verna (L.) Hiern., incl. M. gerardii (Willd.) Hayek and M. pauciflora (Kit. ex Kanitz) Dvořaková, see Fedoronchuk \& Mosyakin, 2016), Saxifraga paniculata Cav., Selaginella selaginoides (L.) Schrank \& Mart., Thymus pulcherrimus Schur, Viola biflora $\mathrm{L}$. and others.

Obs.: Clemens Pachschwöll \& Tetiana Pachschwöll, 22 August 2018; ref. (on digital images): Filip Koláŕ, 17 September 2018. 


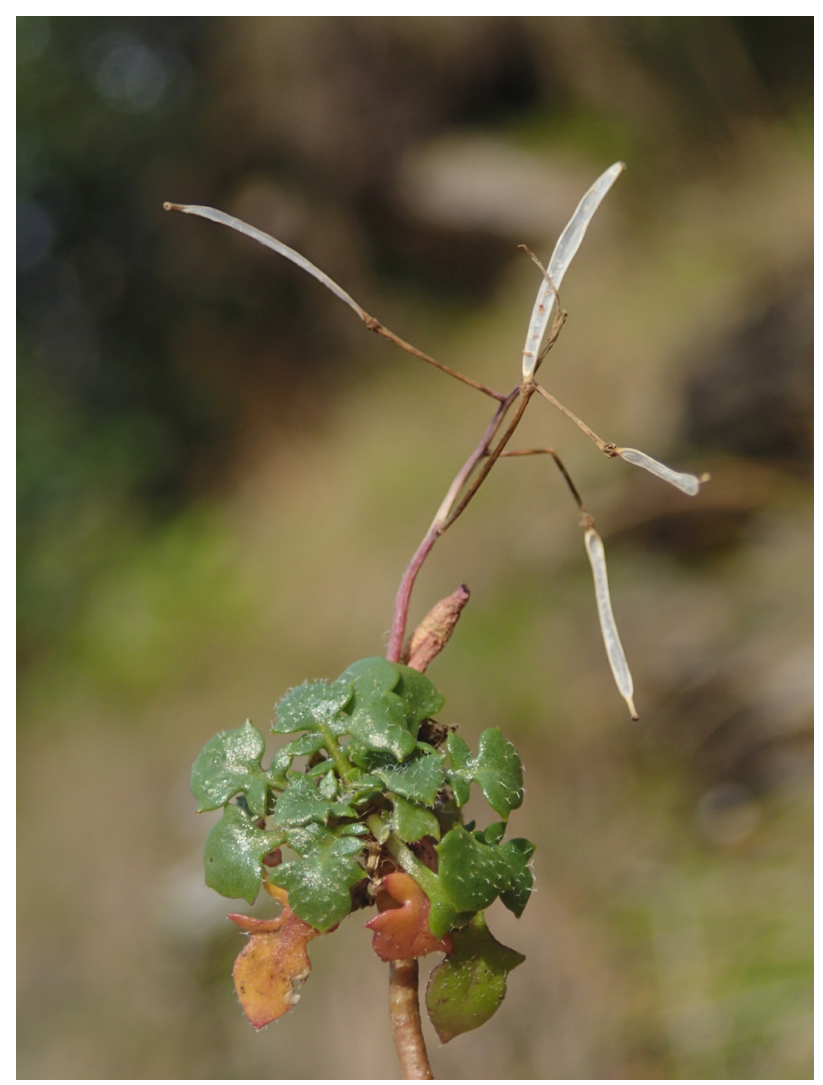

Fig. 3. Arabidopsis neglecta: close-up of a fruiting individual. Photo by Clemens Pachschwöll, 22 August 2018

Arabidsopis neglecta grows here in scree microsites of the association Rumici scutati-Rhodioletum roseae Malinovsky et al. 1991 from alliance PapaveroThymion pulcherrimi I. Pop 1968 (Solomakha, 2008), a phytocoenosis known from other parts of the Svydovets Massif, like Mt. Drahobrat (Malinovskiy, Krichfalusy, 2000; Didukh et al., 2016; Solomakha, 2008; Kobiv et al., 2009).

The botanical importance of calcicole to intermediate subalpine-alpine habitats at the Komyn Cirque is expressed by the number and abundance of threatened species occurring there (Bedei, 2006; Kyyak et al., 2016). According to the Red List for the Ukrainian Carpathians by Kricsfalusy and Budnikov (2007), two taxa (Cerastium eriophorum, Festuca amethystina subsp. orientalis) are vulnerable (VU), six (Achillea oxyloba subsp. schurii, Doronicum columnae subsp. carpaticum, Galium anisophyllon, Rhodiola rosea, Sabulina verna, Saussurea alpina) are endangered $(\mathrm{EN})$, and one (Selaginella selaginoides) is critically endangered (CR). According to the Red Data Book of Ukraine (Chervona knyha..., 2009), Achillea oxyloba subsp. schurii, Campanula kladniana, Sabulina verna (listed as Minuartia pauciflora) and Saussurea alpina are rare and Rhodolia rosea and Selaginella selaginoides are vulnerable. It is worth mentioning, that Komyn harbours the only known population of Saussurea alpina in the Svydovets Massif, which was originally (although erroneously) published as Saussurea discolor (Willd.) DC. (Kardash, Kyyak, 1991). In the Ukrainian Carpathians, Saussurea alpina is a rare arctic-alpine species otherwise known only from the Chornohora (Kyyak, 2009; Cherepanyn, 2017). Another noteworthy species not mentioned in any Red List is the PanCarpathian endemic Thymus pulcherrimus (Novikoff, Hurdu, 2015; Kliment et al., 2016). In Ukraine it is only known from a dozen populations, from Mt. Blyznytsia and Mt. Drahobrat in the Svydovets Massif as well as from the Chornohora and Chyvchyny (Chopyk, Fedoronchuk, 2015; Nachychko, Honcharenko, 2017).

Due to several factors, micropopulations of Arabidsopis neglecta (Fig. 3) in steep slopes of glacial cirques are highly endangered. Very likely, there is no gene flow between them as they are separated geographically in an "island-like" fashion. During a ten-year period of monitoring, Alnus alnobetula (A. viridis) has overtaken next to Saussurea alpina at Komyn, decreasing in suitable microhabitats for pioneer and early-successional cold-dwelling species such as the newly discovered A. neglecta (Kyyak et al., 2016). Less snow cover, less erosion due to snowpack shift, less humidity and prolonged vegetation periods are responsible for the trend demonstrating that low-competitive glareophytes such as A. neglecta are threatened by overgrowth of subalpine scrubs and dwarf shrubs (Didukh et al., 2016; Kobiv, 2017). Due to climate change, this narrow-range taxon is in general decline in other monitored populations of the Ukrainian Carpathians (Kobiv, 2017). In the Chornohora, one monitored population of $A$. neglecta at Mt. Brebeneskul has been gradually shrinking during a 15 -year period (Kobiv, 2018), rendering the discovery of a new population valuable. The unprotected populations from Mt. Gereshaska [Heryshas'ka] (Margittai, 1935) and Mt. Trojaska/polonyna Apshynets (Kobiv et al., 2009) are probably the most endangered ones. They are located c. 0.5 and $1 \mathrm{~km}$ aside, respectively, the projected roads and hotels of the planned gigantomaniac ski and spa resort "Svydovets" (Bedernichek, 2017; https:// freesvydovets.org) which might cause urbanization, pollution and even destruction of the high mountain habitats in the north-central part of the Svydovets 
Massif (Kagalo et al., 2018). All these facts support the categorization "endangered" (EN) for A. neglecta in the Ukrainian Carpathians, as used by Kricsfalusy and Budnikov (2007).

\section{Arabidopsis neglecta in the Carpathians - recent publications and outlook}

The biological knowledge on $A$. neglecta in the Ukrainian Carpathians is scarce and its detailed distribution is still not well known. In the Western and Southern Carpathians (Slovakia and Romania), two cytotypes of $A$. neglecta do exist (Schmickl et al., 2012; Hohmann et al., 2014; Kolář et al., 2016b), A. neglecta subsp. neglecta $(2 n=16)$ and the taxon informally (provisionally) named "subsp. robusta" $(2 n=32)$. For the Ukrainian Carpathians, no cytological or genetic data is available so far (Schmickl et al., 2012; Hohmann et al., 2014; Rice et al., 2014; Koláŕ et al., 2016a, b). More detailed floristic investigations in suitable habitats of the Ukrainian Carpathians could lead to discoveries of further populations, as it has been done in the Southeastern Carpathians by Bartók et al. (2016). Due to the fact that $A$. neglecta is sometimes confused with more common species Arabidopsis arenosa (L.) Lawalrée and A. halleri (L.) O'Kane \& Al-Shehbaz, a critical revision of so far unconfirmed records like that from the Gorgany (Ziman, Tyukh, 2008) - which is not accepted by Chopyk and Fedoronchuk (2015), Novikoff and Hurdu (2015), and Bartók et al. (2016) - should be undertaken. Recent genomic studies showed that the alpine eco- and morphotype of A. neglecta evolved repeatedly from lowland $A$. arenosa in the Carpathians (Kolář et al., 2017, Monnahan et al., 2019), rendering a future reclassification necessary. Regardless of any future classification change, either as an infraspecific entity or just a synonym of $A$. arenosa, - a taxon more widespread in the Ukrainian Carpathians (Kotov, 1953; Sychowa, 1985; Chopyk, Fedoronchuk, 2015) and well known from the Svydovets Massif (Klášterský, 1929), the numerous rare alpine plant species mentioned for Komyn justify this report which should stimulate future research on the genus Arabidopsis in the Ukrainian Carpathians.

\section{Acknowledgments}

We are grateful to Filip Koláŕ (Charles University, Prague) for confirming our identification and to Andriy Novikov (State Natural History Museum, NAS of Ukraine, Lviv) for his help in providing rare literature. Useful comments of Dmitry German (Heidelberg University, Heidelberg, Germany, and
Altay State University, Barnaul, Russia) and Yuriy Kobiv (Institute of Ecology of the Carpathians, NAS of Ukraine, Lviv) provided in their open reviews are greatly appreciated, as well as editorial comments of Sergei Mosyakin (M.G. Kholodny Institute of Botany, NAS of Ukraine, Kyiv).

\section{REFERENCES}

Bartók A., Hurdu B.-I., Szatmari P.-M., Ronikier M., Puşcaş M., Novikoff A., Bartha L., Vonica G. 2016. New records for the high-mountain flora of the Făgăraş Mts. (Southern Carpathians) with discussion on ecological preferences and distribution of studied taxa in the Carpathians. Contributii Botanice Univitâtea "Babes-Bolyai" Cluj-Napoca, 51: 77-153.

Bedei M.I. 2006. Blyznytsi-Drahobrat (flora, vegetation, conservation). Uzhhorod: Lira, 108 pp. [Бедей M.I. 2006. Близниці-Драгобрат (флора, рослинність, охорона). Ужгород: Ліра, 108 с.].

Bedernichek T. 2017. Alpine tundra of the Krkonoše and Carpathian mountains. Regensburg: EUROPARC Federation \& Alfred Toepfer Foundation, 36 pp. Available at: http://www.europarc.org/wp-content/ uploads/2018/04/Alpine-Tundra_Tymur-Bedernichek_ Report.pdf (Accessed 20 January 2019 ).

Cherepanyn R.M. 2017. Artic-alpine plant species of the Ukrainian Carpathians. Ivano-Frankivsk: Publishing House of the Precarpathian National University, 92 pp. [Черепанин Р.М. 2017. Аркто-альпійські види рослин Українських Карпат. Івано-Франківськ: Вид-во Прикарпат. нац. ун-ту, 92 с.].

Chervona knyha Ukrainy. Roslynnyi svit (Red Data Book of Ukraine. Plant Kingdom). 2009. Ed. Ya.P. Didukh. Kyiv: Globalkonsaltyng, 912 pp. [Червона книга України. Рослинний світ. 2009. Ред. Я.П. Дідух. Київ: Глобалконсалтинг, 912 с.].

Chopyk V.I., Fedoronchuk M.M. 2015. Flora Ucrainae Carpaticae. Ternopil: Terno-graph, 712 pp. [Чопик B.I., Федорончук М.М. 2015. Флора Українських Kарпат. Тернопіль: Терно-граф, 712 с.].

Didukh Ya.P., Chorney I.I., Budzhak V.V. 2016. Climatogenic changes of plant life of the Ukrainian Carpathians. Eds Ya.P. Didukh, I.I. Chorney. Chernivtsi: DrukArt, 280 рр. [Дідух Я.П., Чорней І.І., Буджак В.В. 2016. Кліматогенні зміни рослинного світу Українських Kapnam. Ред. Я.П. Дідух, I.I. Чорней. Чернівці: Друк Арт, 280 c.].

Domin K. 1930. Šimanův kotel na Svidovci v Podkarpatské Rusi. Vèstník Královské české společnosti náuk, Třr. Mat.Př́r., 4: 1-20.

Euro+Med (2006-): Euro+Med PlantBase - the information resource for EuroMediterranean plant diversity. Available at: http://ww2.bgbm.org/EuroPlusMed/ (Accessed 20 January 2019).

Fedoronchuk M.M., Mosyakin S.L. 2016. Ukrainian Botanical Journal, 73(2): 134-143. [Федорончук M.M., Мосякін С.Л. 2016. Рід Minuartia s. 1. (Caryophyllaceae) у флорі Східної Європи: огляд номенклатурних змін у світлі нових молекулярно-філогенетичних даних. Украйнський ботанічний журнал, 73(2): 134-143]. https://doi.org/10.15407/ukrbotj73.02.134 
Hohmann N., Schmickl R., Chiang T.-Y., Lučanová M., Kolář F., Marhold K., Koch M.A. 2014. Taming the wild: resolving the gene pools of non-model Arabidopsis lineages. BMC Evolutionary Biology, 14: 224. https://doi. org/10.1186/s12862-014-0224-X

Hurdu B.-I., Puşcaş M., Turtureanu P.D., Niketić M., Coldea G., Zimmermann N.E. 2012. Patterns of plant endemism in the Romanian Carpathians (South-Eastern Carpathians). Contributii Botanice Univitâtea "BabesBolyai" Cluj-Napoca, 47: 25-38.

Jávorka S., Csapody V. 1979. Ikonographie der Flora des südöstlichen Mitteleuropa. Budapest \& Stuttgart: Akadémiai Kiadó \& G. Fischer-Verlag, 703 pp.

Kagalo A., Kanarsky Y., Mykitchak T., Kovtoniuk, O., Kobiv Y., Kyyak V., Sytschak N., Bashta A.-T., Tsaryk J., Dykyy I., Shydlovskyy I., Reshetylo O. 2018. Visnyk Kyivskoho Universytetu im. Tarasa Shevchenka. Series Geografiya, 70(1): 35-46. [Кагало О., Канарський Ю., Микітчак Т., Ковтонюк О., Кобів Ю., Кияк В., Сичак Н., Башта А.-Т., Царик Й., Дикий I., Шидловський I., Решетило О. 2018. Природоохоронне значення території Центрального Свидовця (Українські Карпати). Вісник Киівського університетуту імені Тараса Шевченка. Серія Географія, 70(1): 35-46]. https://doi. org/10.17721/1728-2721.2018.70.6

Kardash Ya.V., Kyyak V.H. 1991. Nove mistseznakhodzhennya Saussurea discolor (Willd.) DC. In: Aktualni problemy vyvchennya fitobioty u zakhidnomu rehioni Ukrainy: Mater. konf. molodykh botanikiv m. Lvova. Lviv, pp. 5456. [Кардаш Я.В., Кияк В.Г. 1991. Нове місцезнаходження Saussurea discolor (Willd.) DC. У зб.: Актуальні проблеми вивчення фітобіоти у західному регіоні України: Матер. конф. молод. ботаніків м. Львова. Львів, с. 54-56].

Klášterský I. 1929. Ad floram Carpatorossicam additamenta critica I. Preslia, 8: 9-32.

Kliment J., Turis P., Janišová M. 2016. Taxa of vascular plants endemic to the Carpathian Mts. Preslia, 88: 19-76.

Kobiv Y.Y. 2011. Ukrainian Botanical Journal, 68(5): 635650. [Кобів Ю.Й. 2011. Периферійні популяції рідкісних видів рослин Українських Карпат. Український ботанічний журнал, 68(5): 635-650].

Kobiv Y. 2017. Response of rare alpine plant species to climate change in the Ukrainian Carpathians. Folia Geobotanica, 52: 217-226. https://doi.org/10.1007/ s12224-016-9270-Z

Kobiv Y. 2018. Trends in population size of rare plant species in the alpine habitats of the Ukrainian Carpathians under climate change. Diversity, 10(3): 62. https://doi. org/10.3390/d10030062

Kobiv Y., Prokopiv A., Helesh M., Borsukevich L. 2009. Visnyk Lvivskoho universytetu. Series Biology, 49: 63-82. [Кобів Ю., Прокопів А., Гелеш М., Борсукевич Л. 2009. Поширення, стан популяцій та характеристика оселищ рідкісних і загрожених видів рослин у північній частині Свидовця (Українські Карпати).
Вісник Львівського університету. Серія біологічна, 49: 63-82].

Kolář F., Fuxová G., Záveská E., Nagano A.J., Hyklová L., Lucanová M., Kudoh H., Marhold K. 2016. Northern glacial refugia and altitudinal niche divergence shape genome-wide differentiation in the emerging plant model Arabidopsis arenosa. Molecular Ecology, 25(16): 39293949. https://doi.org/10.1111/mec.13721

Kolář F., Lučanová M., Záveská E., Fuxová G., Mandáková T., Španiel S., Senko D., Svitok M., Kolník M., Gudžinskas Z., Marhold K. 2016. Ecological segregation does not drive the intricate parapatric distribution of diploid and tetraploid cytotypes of the Arabidopsis arenosa group (Brassicaceae). Biological Journal of the Linnean Society, 119: 673-688. https://doi.org/10.1111/ bij. 12479

Kolář F., Fuxová G., Knotek A., Záveská E., Marhold K. 2017. Phylogeography of Carpathian plants above and below the timberline - case study of two Arabidopsis species with pronounced altitudinal ecotypic variation. Studia Universitatis Babeş-Bolyai. Series Biologia. Spec. Issue, 62: 47.

Kotov M.I. 1953. Cruciferae. In: Flora URSR, vol. 5. Ed. M.V. Klokov. Kyiv: Ukr. RSR Acad. Sci. Publ., pp. 203429, p. 650. [Котов М.I. 1953. Cruciferae. В кн.: Флора Української РСР, т. 5. Ред. М.В. Клоков. Київ: Вид-во AH УРСР, c. 203-429, c. 650].

Kricsfalusy V., Budnikov G. 2007. Threatened vascular plants in the Ukrainian Carpathians: current status, distribution and Conservation. Thaiszia, 17: 11-32.

Kyyak V. 2009. Saussurea alpina. In: Chervona knyha Ukrainy. Roslynnyi svit (Red Data Book of Ukraine. Plant Kingdom). Ed. Ya.P. Didukh. Kyiv: Globalconsulting, p. 333. [Кияк В. 2009. Saussurea alpina. В кн.: Червона книга України. Рослинний світ. Ред. Я.П. Дідух. Київ: Глобалконсалтинг, с. 333].

Kyyak V., Shtupun V., Bilonoha V. 2016. Visnyk Lvivskoho universytetu. Series Biology, 74: 104-115. [Кияк В., Штупун В., Білонога В. 2016. Кліматогенні загрози популяціям рідкісних і ендемічних видів рослин високогір'я Українських Карпат. Вісник Львівського університету. Серія біологічна, 74: 104-115].

Malinovski K.A., Kricsfalusy V.V. 2000. High mountain vegetation. In: Vegetation of the Ukraine, vol. 1. Ed. V. Solomakha. Kyiv: Phytosociocentre, 230 pp. [Малиновський К.А, Крічфалушій В.В. 2000. Високогірна рослинність. В кн.: Рослинність України, т. 1. Ред. В.А. Соломаха. Київ: Фітосоціоцентр, 230 с.].

Malinovski K., Tsaryk Y., Kyyak V., Nesteruk Y. 2002. Rare, endemic, relict and marginally ranged plant species of the Ukrainian Carpathians. Lviv: Liga-Press, 76 рр. [Малиновський К., Царик Й., Кияк В., Нестерук Ю. 2002. Рідкісні, ендемічні, реліктові та погранично-ареальні види рослин Українських Kарпат. Львів: Ліга-Прес, $76 \mathrm{c.}$.$] .$

Margittai A. 1935. A Körösmezei (Jaszinai) Pietrosz-havas flórája. Die Flora des Körösmezöér (Jasinaer) Pietros. Botanika közlemények, 32: 75-91.

Marhold K. 2011. Brassicaceae. In: Euro+Med Plantbase - the information resource for Euro-Mediterranean 
plant diversity. Available at: http://ww2.bgbm.org/EuroPlusMed/ (Accessed 20 January 2019).

Monnahan P., Kolář F., Baduel P., Sailer C., Koch J., Horvath R., Laenen B., Schmickl R., Paajanen P., Šámková G., Bohutínská M., Arnold B., Weisman C.M., Marhold M., Slotte T., Bomblies K., Yant L. 2019. Pervasive population genomic consequences of genome duplication in Arabidopsis arenosa. Nature Ecology \& Evolution, 3: 457-468. https://doi.org/10.1038/ s41559-019-0807-4.

Nachychko V., Honcharenko V. 2017. Visnyk Lvivskoho universytetu. Series Biology, 75: 35-47. [Начичко В., Гончаренко В. 2017. Ботаніко-географічна характеристика видів роду Thymus L. (Lamiaceae) у флорі західних регіонів України. Вісник Львівського університету. Серія біологічна, 75: 35-47].

Novikoff A., Hurdu B.-I. 2015. A critical list of endemic vascular plants in the Ukrainian Carpathians. Contributii Botanice Univitâtea "Babes-Bolyai" Cluj-Napoca, 50: 43-91.

Pachschwöll C. 2013. Lectotypification of Doronicum carpaticum (Griseb. \& Schenk) Nyman (Asteraceae), with some remarks on its distribution and taxonomy. Contributii Botanice Univitâtea "Babes-Bolyai" Cluj-Napoca, 48: 7-14.

Rice A., Glick L., Abadi S., Einhorn M., Kopelman N., Salman-Minkov A., Mayzel J., Chay O., Mayrose I. 2014. The Chromosome Counts Database (CCDB) - a community resource of plant chromosome numbers. New Phytologist, 206: 19-26. https://doi.org/10.1111/ nph.13191

Schmickl R., Paule J., Klein J., Marhold K., Koch M.A. 2012. The evolutionary history of the Arabidopsis arenosa complex: Diverse tetraploids mask the Western Carpathian center of species and genetic diversity. PLoSONE, 7(8): e42691. https://doi.org/10.1371/journal.pone.0042691.

Solomakha V.A. 2008. Syntaksonomiya roslynnosti Ukrainy. Tretye nablyzhennya. Kyiv: Phytosociocentre, 296 pp. [Соломаха В.А. 2008. Синтаксономія рослинності України. Третє наближсення. Київ: Фітосоціоцентр, 296 c.].

Sychowa M. 1985. Cardaminopsis (C.A.Maer) Hayek, Rzeżusznik. In: Flora Polski, Rośliny naczyniowe, vol. 4. Ed. A. Jasiewicz. Warszawa-Kraków: PWN, pp. 203-208.

Ziman S.M., Tyukh Y.Y. 2008. Ukrainian Botanical Journal, 65(4): 513-519. [Зиман С.М., Тюх Ю.Ю. 2008. Біоморфологічний аналіз рідкісних таксонів судинних рослин у флорі національного природного парку "Синевир". Український ботанічний журнал, 65(4): 513-519].

Recommended for publication by S.L. Mosyakin 